\title{
Penerapan Model Pembelajaran Kooperatif Tipe Stand (Student Team Achivement Division) Guna Meningkatkan Pemahaman dan Hasil Belajar Siswa pada Pelajaran Wadah Budidaya Perikanan di Kelas II TBP Sekolah Usaha Perikanan Menengah (SUPM) Negeri Sorong
}

\author{
Elmi Hidayah \\ SUPM Negeri Sorong \\ Elmihidayah9@gmail.com
}

\begin{abstract}
Abstrak : Penelitian Tindakan kelas (PTK) ini bertujuan untuk meningkatkan hasil belajar siswa kelas II TBP SUPM N Sorong melalui model pembelajaran tipe STAD. Secara garis besar terdapat empat tahapan PTK, yaitu (1) perencanaan, (2) pelaksanaan, (3) pengamatan, dan (4) refleksi.Penelitian ini dilakukan sebanyak 3 siklus, siklus 1 sebagai data perbandingan untuk siklus 2 dan 3.Jumlah siswa yang aktif dalam penelitian ini sebanyak 30 orang siswa.Hasil penelitian menunjukan bahwa model pembelajaran kooperatif tipe STAD dapat memberikan hasil belajar yang lebih bai. Hal ini dapat dilihat dengan rata- rata perolehan nilai pada siklus 138.06 dan milai ketuntasan belajar $16.6 \%$ kemudian terjadi peningkatan nilai rata- rata pada siklus 2 dan 3 dengan pembelajaran kooperatif tipe STAD yaitu, siklus 2 nilai rata- rata kelas 73.3 dengan presentase ketuntasan belajar $76.6 \%$ dan siklus 3 nilai rata- rata kelas 74.16 dengan presentase ketuntasan belajar $90 \%$. Begitupun dengan aktifitas siswa mengalami peningkatan.
\end{abstract}

Kata Kunci : Kooperatif Tipe STAD; Hasil Belajar; Membuat wadah Budidaya Perikanan.

Abstract:This classroom action research (CAR) aims to improve the learning outcomes of class II TBP SUPM N Sorong through the STAD type learning model. For the outline, there are four stages of CAR, namely (1) planning, (2) implementation, (3) observation, and (4) reflection. This research was conducted in 3 cycles, cycle 1 as comparison data for cycles 2 and 3. The number of students who were active in this study was 30 students. The results showed that the STAD type of cooperative learning model can provide better learning outcomes. This can be seen by the average value acquisition in cycle 138.06 and learning completeness score 16.6\% then an increase in the average value in cycles 2 and 3 with cooperative learning type STAD, namely, cycle 2 class average value of 73.3 with a percentage of completeness learning $76.6 \%$ and cycle 3 class average value of 74.16 with a percentage of learning completeness 90\%. Likewise with student activity has increased.

Keywords: cooperative type STAD; Learning Outcomes; Making fishery cultivation containers

\section{Pendahuluan}

Pendidikan dan pengajaran adalah suatu usaha sadar yang system matik untuk mencapai tujuan terhadap perilaku peserta didik dalam melakukan perubahan- perubahan untuk menuju kedewasaan. Adapun proses yang dimaksud tersebut adalah proses pembelajaran, hal ini dinyatakan dalam undang- undungan No. 20 tahun 2003 tentang Sistem Pendidikan Nasional, bahwa pendidikan adalah usaha dan terencana untuk mewujudkan suasana belajar dan proses pembelajran yang konduktif agar peserta didik secara aktif dapat menumbuh kembangkan potensi yang ada pada dirinya untuk dapat memiliki kekuatan spiritual keagamaan, pengendalian diri, kepribadian, kecerdasan, akhlak mulia, serta keterampilan yang diperlakukan dirinya, masyarakat, bangsa dan Negara.

Dalam proses belajar mengajar tidak lepas dari tiga komponen utama yaitu : guru, siswa, dan bahan ajar. Unsur utama adalah siswa, kebutuhan sebagai sumber, serta situasi belajar yang memberikan kemungkinan kegiatan belajar.Meskipun demikian guru- guru merupakan factor yang cukup menetukan, seperti melakukan pengembangan bahan ajar serta perangkat lainnya. Menurut Wina (2012), model pembelajarn kooperatif adalah rangkaian kegiatan belajar yang dilakukan oleh siswa dalam kelompok- kelompok tertentu yang digunakan untuk mencapai tujuan pembelajaran. Oleh karena itu pembelajran kooperatif tidak hanya bertujuan untuk menyelesaikan tugas yang 
diberikan pada kelompok tersebut melainkan merupakan model pembelajaran yang menekankan pada tanggung belajar individu dalam kelompok. Selanjutnya Chotimah dan Dwitasari dalam Munawwarah et all (2015), menyebutkan karakteristik pembelajaran kooperatif : 1) peserta didik bekerja dalam kelompok kooperatif untuk menguasai materi akademi, 2) anggota- anggota dalam kelompok diatur terdiri dari peserta didik yang berkemampuan rendah, sedang dan tinggi, 3) jika memungkinkan, masing- masing anggota kelompok kooperatif berbeda suku, budaya dan jenis kelamin, 4) system penghargaan yang berorientasipada kelompok dari pada individu.

Menurut siswa model yang digunakan model ceramah, Tanya jawab dan pemberian tugas sementara pelaksanaan penilaian hanya mengandalkan pada ujian tertulis saja.Hal ini menjadi penyebab rendahnya hasil belajar siswa pada mata pelajaran wadah budidaya perikanan, terbukti dengan masih banyaknya siswa yang harus melakukan ujian perbaikan (remedial) pada mata pelajaran wadah budidaya.Pada mata pelajaran ini, kendala yang banyak dihadapi oleh siswa adalah sulitnya memahami materi yang telah diajarkan oleh guru, oleh karena itu penelitian ini perlu dilaksanakan untuk meberikan solusi yang tepat dalam mengahadapi permasalahan tersebut.Penerapan model pembelajaran kooperatif tipe Student Teams Achievement Division (STAD) memungkinkan bisa meningkatkan hasil belajar siswa dalam mata pelajaran Wadah Budidaya Perikanan. Berdasarkan hasil uraian diatas, maka dipandang perlu dilakukan penelitian dengan judul “ Penerapan Model Pembelajaran Kooperatif Tipe Stad Guna Meningkatkan Pemahaman Dan Hasil Belajar Siswa Pada Pelajaran Wadah Budidaya Perikanan Dikelas II TBP SUPMN Sorong".

\section{Metode Penelitian}

Penelitian ini adalah penelitian tindakan kelas (Classroom Action Research) dengan tahapantahapan pelaksanaan meliputi; perencanaan, pelaksanaan,/ tindakan, evaluasi dan refleksi secara berulang- ulang. Subyek penelitan adalah siswa kelas II semester 3 (tiga) tahun ajaran 2016/2017 Program Studi Teknologi Budidaya Perikanan sebanyak 30 peserta didik dengan sasaran penelitian, yaitu adanya peningkatan motivasi dan hasil belajar yang dapat dicapai setelah proses belajar mengajar selesai dilaksanakan.

Prosedur Penelitian Tindakan Kelas (PTK) ini dilakukan dalam 3 (tiga) siklus.Setiap siklus dilaksanakan 2 kali pertemuan (6 jam pelajaran). Sebelum memasuki siklus 2 (dua) terlebih dahulu dilakukan siklus 1 (satu) dalam siklus 1 belum dilakukan pembelajaran kooperatif tipe STAD dengan tujuan sebagai control atau perbandingan hasil belajar serta dilakukan tes awal yang diguanakn sebagai acuan dalam pembagian kelompok, kemampuan memahami pelajaran. Gambaran umum yang dilakukan pada setiap siklus adalah perencanaan (plan), pelaksanaan (act), pengamatan (observe), dan refleksi (reflect) yang digambarkan pada gambar 1:

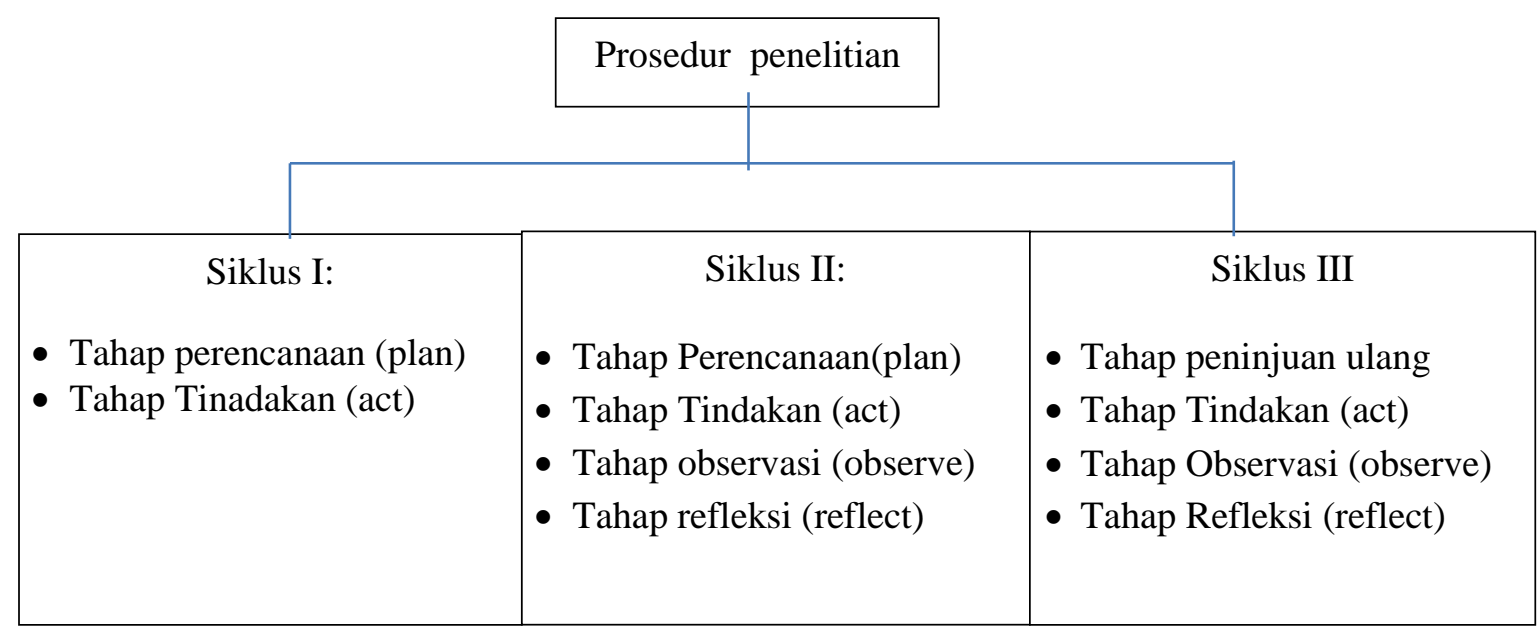

Dalam pengambilan data dimaksudkan untuk melihat seberapa jauh efek tindakan telah mencapai sasaran. Data yang diambil disini adalah : 
a. Data kuantitaf berupa hasil belajar

b. Data kualitatif berupa hasil observasi seperti kehadiran siswa, keaktifan bertanya dan mengajukan tanggapan, siswa melakukan kegiatan yang lain- lain yang terdapat pada lembar observasi.

Indicator keberhasilan dalam penelitian ini adalah apabila telah terbentuk keterampilan social dalam diri siswa.Hal ini dapat dilihat dalam keaktifan siswa dalam kegiatan kelompok (Diskusi maupun member tanggapan), bertanya materi yang belum dimengerti, meminta bimbingan materi yang belum dimengerti. Selain itu terjadi peningkatan nilai rata-rata hasil belajar yang diperoleh siswa setelah dilaksanakan proses belajar mengajar melalui pembelajaran kooperatif tipe STAD. Bila skor rata- rata hasil belajar/ ketuntasan belajar siswa mengalami peningkatan menurut ketentuan siswa dikatakan tuntas belajar apabila skor minimal 7.00 dari skor ideal dan tuntas belajar secara klasikal apabila 75\% dari jumlah siswa telah tuntas belajar.

\section{Hasil dan Pembahasan}

Hasil dan analisis data penelitian ini dibuat berdasarkan data yang diperoleh dari kegiatan penelitian tentang hasil belajar siswa pada mata pelajaran Membuat Wadah Budidaya Perikanan melalui pembelajaran kooperatif tipe STAD yang dilaksanakan di SUPM Negeri Sorong.Pelaksanaan penelitian ini dilakukan selama 3 siklus. Adapun yang dianalisis adalah hasil tes awal atau siklus 1, tes akhir siklus 2 dan siklus 3, serta data tambahan berupa perubahan sikap siswa yang diperoleh dari hasil pengamatan terhadap siswa selama penelitian berlangsung.

Berdasarkan analisis deskriptif tes awal (siklus I) bahwa skor rata-rata belajar siswa pada mata pelajaran membuat Wadah Budidaya Perikanan pada siklus I adalah 38.06 dari skor ideal, yaitu 70.00. skor maksimum yang diperoleh siswa adalah 70.00, skor minimum 15.00 dan rentang skor adalah 55.00. apabila kemampuan siswa dalam penyelesaian soal-soal tes awal (siklus I) dianalisis, maka presentase ketuntasan belajar siswa dapat dilihat bahwa pada tes awal ketuntasan belajar siswa sebesar $16.6 \%$ yaitu 5 dari 30 siswa termasuk dalam kategori tuntas, sedangkan $83.3 \%$ atau 25 dari 30 siswa termasuk dalam kategori belum tuntas. Hal ini menunjukan bahwa dari 30 jumlah siswa masih ada 25 siswa yang belum tuntas hasil belajarnya dan memerlukan pada pembelajaran siklus 2 .

Hasil belajar siswa pada siklus 2 meunjukan bahwa hasil ketuntasan belajar pada siklus 2 sebesar $76.6 \%$ atau 23 dari 30 siswa berada dalam kategori tuntas dan $23.3 \%$ atau 7 dari 30 siswa berada dalam kategori tidak tuntas. Karena berdasarkan kriteria hasil belajar mengenai ketuntasan kelas secara klasikal, yaitu $75 \%$ dari jumlah siswa yang tuntas. Tetapi ada beberapa hal yang diperlu dilakukan perbaikan pada siklus berikutnya dana guna mendukung hasil belajar pada siklus 2. Dari observasi yang dilakukan pada siklus 2 ternyata masih ada beberapa hal yang perlu diperbaikan yaitu masih banyaknya siswa yang melakukan kegiatan lain dan keaktifan siswa pada saat diskusi kelompok masih rendah.Dari hasil analisis kualitatif yang diperoleh melalui lembar observasi diatas terdapat beberapa masalah yang diperlu direfleksikan guna perbaikan pada siklus selanjutnya atau siklus 3 sehingga hal- hal yang masih kurang dapat ditingkatkan.

Hasil belajar siswa pada siklus 3 setelah melalui perbaikan tindakan menunjukkan bahwa presentase hasil ketuntasan belajar pada siklus 3 sebesar $90 \%$ atau 27 siswa dari 30 siswa berada dalam kategori tuntas dan $10 \%$ atau 3 siswa dari 30 siswa berada dalam kategori tidak tuntas. Karena berdasarkan kriteria hasil belajar mengenai ketuntasan kelas seacara klasikal, yaitu 75\% dari jumlah siswa yang tuntas, data hasil penelitian dari siklus 3 yaitu hasil belajar siswa diangggap tuntas karena mencapai $90 \%$ yang berarti telah melebihi kriteria ketuntasan belajar secara klasikal. Namun untuk siswa yang belum memenuhi kriteria tersebut akan dilakukan perbaikan dengan mengadakan remedial. Setelah dilakukan siklus 3 terjadi perbaikan- perbaikan yaitu siswa yang melakukan kegiatan lain pada saat diskusi kelompok berlangsung sudah berkurang dibandingkan pada saat siklus 2, kemudian pengawasan guru terhadap siswa pada saat diskusi berlangsung sudah 
bisa menjangkau semua kelompok sehingga siswa lebih focus pada kegiatan diskusi dari pada melakukan kegiatan lainnya, dan keakatifan siswa dalam diskusi kelompok semakin meningkat.

Dari observasi yang dilakukan selama dua siklus dengan menerapkan model pembelajaran kooperatif tipe STAD memberikan banyak perubahan kepada siswa, yaitu siswa lebh termotivasi untuk giat belajar, siswa merasa senang dengan model yang diterapkan, siswa lebih akrap dengan siswa yang lain, dan siswa lebih termotivasi dalam mengerjakan soal LKS. Dari perubahan diatas menunjukan bahwa perolehan nilai rata-rata kelas pada siklus $138.06 \%$, terjadi kenaikan pada siklus 2 dengan perolehan nilai rata-rata 73.3 dan siklus 3 diperoleh nilai rata-rata $74.16 \%$. berdasarkan pada indicator keberhasilan, siswa dikatakan tuntas hasil belajarnya apabila memperoleh skor minimal 70.00 dari skor ideal 100, dan tuntas secara klasikal jika $75 \%$ dari jumlah siswa yang telah tuntas hasil belajarnya. Maka hasil belajar siswa dari siklus 2 sampai pada siklus 3 meningkat dan telah memenuhi indicator keberhasilan.

\section{Kesimpulan dan Saran}

Berdasarkan hasil analisis data dan pembahasan, maka dapat ditarik kesimpulan bahwa penerapan model pembelajaran kooperatif tipe STAD pada mata pelajaran Membuat Wadah Budidaya Perikanan dengan standar Kompetisi Membuat Tambak dan Kopetensi Dasar Membuat kontruksi Tambak, membuat Bestek dan rencana Biaya Pembuatan tambak. Siswa kelas II Teknologi Budidaya Perikanan (TBP) SUPM N Sorong dapat meningkatkan hasil belajar siswa. Hal ini dapat dilihat dengan peningkatan hasil belajar yang pada siklus 1 pembelajaran tanpa menggunakan metode kooperatif tipe STAD hanya mencapai $13.3 \%$ sehingga belum tuntas secara klasikal. Namun pada siklus 2 telah mencapai $76.6 \%$ dan siklus 3 mencapai $90 \%$ ketuntasan secara klasikal.

Berdasarkan hasil yang diperoleh selama penelitian dan demi mencapai hasil yang optimal, maka perlu beberapa hal yang disarankan :

1. Diharapkan kepada guru SUPM N Sorong dapat menerapkan model pembelajaran kooperatif tipe STAD sebagai salah satu model dalam proses pembelajaran dikelas.

2. Diharapkan kepada siswa agar lebih serius dalam menjalankan model pembelajaran kelompok yang nantinya diterapkan oleh guru agar dapat meningkatkan keaktifan dan hasil belajar.

3. Diharapkan kepada peneliti selanjutnya dalam bidang pendidikan khususnya peneilti tindakan kelas agar dapat meneliti lebih lanjut tentang model yang efektif dan efisisen untuk mengatasi kesulitan belajar siswa. 


\section{Daftar Pustaka}

Abdorrakhman Gintings, 2008. Belajar dan Pembelajaran.Humoniora. Bandung.

Arifin, Zainal. 2010. Evaluasi Pembelajaran. Bandung : PT. Remaja Rosdakarya

Haling, Abdul. 2007. Belajar dan Pembelajaran. Makassar.UMN.

Djamarah, S.B. \& Aswan Z., (2013). Strategi Belajar Mengajar. Jakarta: Rineke Cipta

Hasriani.2003. Peningkatan Hasil Belajar Matematika melalui model pembelajaran cooperative learningdengan pendekatan STAD pada siswa kelas IIA SLTP Negeri 21 Makassar. Skripsi Jurusan Matematika FMIPA UNM. Makassar.

Husnul Chotimah dan Yuyun Dwitasari. 2009. Strategi-strategi Pembelajaran. Pena Gumilang. Jakarta.

Huda Miftahul. 2013. Coopratif Learning. Pustaka belajar. Yogayakarta.

Rusman. 2012. Model-model Pembelajaran. JPT Raja Grafindo Persada. Jakarta.

Slameto. 2003. Belajar dan Faktor-faktor yang Mempengaruhi. Jakarta : Rineka Cipta

Slavin, Robert. E. 2005. Cooperatif Learning :teori, riset dan praktek. Bandung : Nusa Media

Trianto. 2007. Model - model pembelajaran Inovatif Berorientasi kontruktivistik. Jakarta : Hasil Pustaka.

Wina Sanjaya. 2012. Penelitian Tindakan kelas.Kencana. Jakarta. 